\title{
Media pembelajaran Si Maspro untuk meningkatkan kemampuan belajar mandiri dan hasil belajar siswa
}

\author{
Kornelia Agata Sari, Madziatul Churiyah* \\ Universitas Negeri Malang, Jl. Semarang No. 5 Malang, Jawa Timur, Indonesia \\ *Penulis korespondensi, Surel: madziatul.churiyah.fe@um.ac.id
}

Paper received: 3-3-2021; revised: 24-3-2021; accepted: 28-3-2021

\begin{abstract}
Abstrak
Pemberlakuan kebijakan Pembelajaran Jarak Jauh (PJJ) untuk memutus mata rantai penyebaran Covid-19 di Indonesia serta perkembangan teknologi yang semakin pesat dapat dimanfaatkan oleh guru dalam pembelajaran yang berdampak pada kemandirian dan hasil belajar peserta didik. Selain itu, perkembangan teknologi juga dapat dimanfaatkan oleh guru untuk melakukan pembelajaran pada abad 21 yaitu pebelajaran yang dirancang untuk mencetak peserta didik abad 21 yang dapat bekerja sama, melakukan komunikasi yang baik, berpikir kritis dan kreatif. Salah satu pemanfaatan teknologi dalam proses pembelajaran yaitu dengan menggunakan media pembelajaran berbasis android, sebagaimana peserta didik sudah tidak asing lagi dengan penggunaan smartphone dalam kehidupan sehari-harinya. Prosedur dan pengembangan dalam penelitian ini menggunakan metode research and development Borg and Gall yang telah dimodifikasi menjadi 8 tahapan. Teknik analisis data yang digunakan yaitu pendekatan kualitatif untuk menganalisis kritik dan saran dan pendekatan kuantitatif untuk menganalisis hasil validasi pakar menggunakan deskriptif persentase dan menganalisis kemandirian serta hasil belajar peserta didik. Hasil penelitian dan pengembangan ini berupa media pembelajaran berbasis android bernama Si-Maspro (Aplikasi Humas dan Keprotokolan) yang telah dinyatakan sangat valid dan layak digunakan dalam pembelajaran otomatisasi tata kelola humas dan keprotokolan kelas XII Otomatisasi Tata Kelola Perkantoran (OTKP) oleh ahli materi, ahli media, serta 6 peserta didik uji coba kelompok kecil. Media pembelajaran Si-Maspro telah terbukti dapat meningkatkan kemandirian dan hasil belajar peserta didik setelah dilakukan uji coba pada kelompok besar. Kesimpulan dari media pembelajaran SiMaspro yaitu layak dan efektif digunakan sebagai media pembelajaran untuk meningkatkan kemandirian dan hasil belajar peserta didik pada mata pelajaran otomatisasi tata kelola humas dan keprotokolan.
\end{abstract}

Kata kunci: penelitian dan pengembangan; media pembelajaran; android; kemandirian belajar; hasil belajar; otomatisasi tata kelola humas dan keprotokolan

\section{Pendahuluan}

Coronavirus Disease (Covid-19) telah menjadi masalah kesehatan dan menggemparkan dunia sejak akhir tahun 2019. Indonesia juga menjadi salah satu negara yang terjangkit virus Covid-19. Penyebaran virus Covid-19 di Indonesia terbilang sangat cepat sehingga membuat masyarakat panik serta banyak memakan korban jiwa. Seluruh lapisan masyarakat harus menerapkan protokol kesehatan dengan melakukan pembatasan sosial (social distancing) dan menjaga jarak fisik (physical distancing) agar mata rantai penyebaran Covid-19 dapat terputus. Pemerintah juga turut membuat kebijakan-kebijakan dalam menangani kasus Covid-19, salah satunya dalam bidang pendidikan dengan diberlakukannya kegiatan Pembelajaran Jarak Jauh (PJJ). Secara tidak langsung, siswa tetap melakukan kegiatan pembelajaran secara daring (online) dengan bantuan media pembelajaran yang telah disiapkan oleh guru sehingga diharapkan kebijakan ini dapat mengurangi resiko penyebaran virus Covid-19.

Kemajuan teknologi yang semakin pesat juga mendorong terjadinya perubahan, terutama dalam bidang pendidikan. Adanya perkembangan teknologi yang semakin pesat ini 
diharapkan dapat dimanfaatkan oleh guru untuk berinovasi dalam mengembangkan media pembelajaran, sehingga dapat membantu dan menunjang proses pembelajaran yang lebih baik khususnya dalam masa pandemi Covid-19. Salah satu inovasi dalam kemajuan teknologi ini yaitu mengembangkan media pembelajaran mobile learning (M-Learning) yang dapat diakses melalui smartphone untuk membantu proses pembelajaran, selain guru serta peserta didik sudah tidak asing dengan pengoperasian smartphone, guru juga memiliki peluang besar untuk pembelajaran yang relevan serta menarik sehingga peserta didik lebih mudah memahami materi yang abstrak menjadi lebih konkrit serta dapat mengefisiensi kegiatan pembelajaran tanpa dibatasi ruang dan waktu, (Rifai et al., 2020), (Suartama et al., 2019), (Restami et al., 2019), (Warsita, 2018).

Setiap kegiatan pembelajaran memiliki tujuan pembelajarannya. Salah satu tujuan pembelajaran pada mata pelajaran Otomatisasi Tata Kelola Humas dan Keprotokolan yaitu untuk meningkatkan kemandirian dan hasil belajar peserta didik. Kemandirian belajar peserta didik ini bertujuan agar peserta didik dapat mengatur kegiatan belajar, memperoleh informasi atau keterampilan yang melibatkan penetapan tujuan, pemantauan diri, mengelola waktu dan mengatur upayanya sendiri untuk mencapai tujuan pembelajaran secara mandiri, (Tabuenca et al., 2015), (Tahar, 2006). Adapun tujuan pembelajaran selain meningkatkan kemandirian belajar yaitu meningkatkan hasil belajar peserta didik pada ranah kognitif terutama dalam pembelajaran yang dilakukan secara daring selama pandemi Covid-19.

Penelitian sebelumnya juga pernah mengembangkan media pembelajaran mobile learning pada mata pelajaran Korespondensi, Perekayasaan Sistem Antena, dan Geografi untuk meningkatkan kemandirian dan hasil belajar peserta didik yang memperoleh hasil bahwa dengan menggunakan media pembelajaran mobile learning praktis dalam penggunaanya sehingga layak digunakan untuk mendukung kemandirian dan hasil belajar peserta didik, (Susanto, 2018), (Firdausi and Santosa, 2016), (Rahmawati and Mukminan, 2018). Berdasarkan hal tersebut peneliti tertarik untuk mengembangkan media pembelajaran berbasis android pada mata pelajaran Otomatisasi Tata Kelola Humas dan Keprotokolan kelas XII OTKP di SMK Negeri 1 Boyolangu Tulungagung.

\section{Metode}

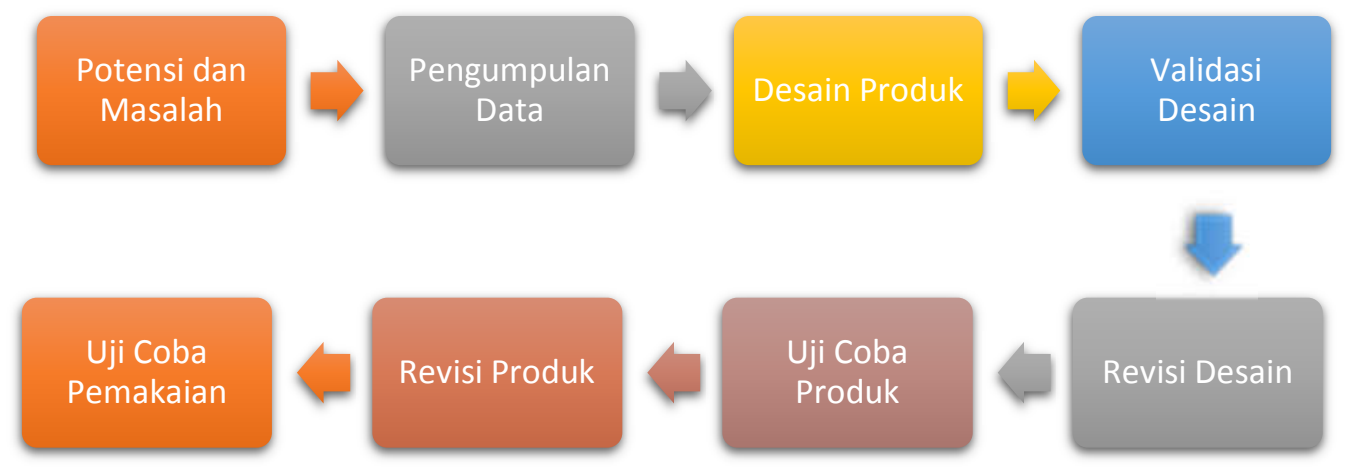

Gambar 1. Langkah-langkah penelitian

Model penelitian dan pengembangan ini menggunakan Research and Development oleh Brog and Gall yang telah dimodifikasi menjadi 8 tahapan sesuai dengan kebutuhan dan kondisi di lapangan. Tujuan penelitian dan pengembangan ini dilakukan untuk menghasilkan produk berupa media pembelajaran berbasis Si-Maspro, mengetahui kelayakan produk, mengetahui 
perbedaan kemandirian dan hasil belajar peserta didik antara yang menggunakan media dan yang tidak menggunakan media pembelajaran yang telah dikembangkan.

Adapun langkah-langkah yang dilakukan yaitu (1) melakukan analisis potensi dan masalah yang terjadi di sekolah melalui wawancara dan observasi, (2) melakukan pengumpulan data dengan menggunakan metode wawancara, angket validasi, dan lembar tes, (3) melakukan perancangan desain produk sebagai salah satu solusi dalam masalah yang terjadi di lapangan, (4) dilakukan validasi desain untuk mengetahui kelayakan media yang telag dikemabangkan, (5) melakukan revisi desain atau perbaikan produk yang sedang dikembangkan dengan acuan kritik dan saran yang telah diberikan oleh validator, (6) produk yang telah direvisi kemudian diuji cobakan kepada kelompok kecil yaitu 6 peserta didik kelas XII OTKP 4 yang memiliki kemampuan heterogen, (7) setelah dilakukan uji coba pada kelompok kecil kemudian dilakukan revisi desain sesuai dengan kritik dan saran yang diberikan oleh peserta didik pada kelompok kecil, (8) produk yang telah di revisi kemudian dilakukan uji coba pemakaian, yaitu diuji cobakan kepada kelas XII OTKP 4 atau kelas eksperimen yang melibatkan, sedangkan kelas kontrol yaitu kelas yang tidak menggunakan media pembelajaran yang telah dikembangkan pada kelas XII OTKP 3,masing-masing kelas memiliki 36 peserta didik.

Data yang diperoleh peneliti yaitu berupa data kualitatif yang berupa kritik dan saran yang diberikan oleh validator serta 6 peserta didik pada kelompok kecil. Data kualitatif diperoleh dari skor angket yang telah diberikan oleh ahli materi, ahli media, peserta didik serta hasil belajar peserta didik. Metode yang digunakan untuk menganalisis kemandirian belajar yaitu dengan metode deskriptif persentase untuk mengetahui perbedaan kemandirian belajar peserta didik yang menggunakan dan yang tidak menggunakan media belajar. Sedangkan metode yang dilakukan untuk mengetahui hasil belajar peserta didik yaitu dengan metode deskriptif presentase, yaitu rata-rata posttest peserta didik pada kelas eksperimen dan kelas kontrol.

\section{Hasil dan Pembahasan}

Produk yang dihasilkan dalam penelitian dan pengembangan ini berupa media pembelajaran berbasis android yang diberi nama Si-Maspro (Aplikasi Humas dan Keprotokolan). Si-Maspro dapat digunakan oleh peserta didik kelas XII OTKP serta guru dalam mata pelajaran Tata Kelola Humas dan Keprotokolan pada KD 3.11 sampai KD 3.16. Menumenu yang disajikan pada Si-Maspro dapat dijelaskan melalui Gambar 2 sampai Gambar 4 sebagai berikut.

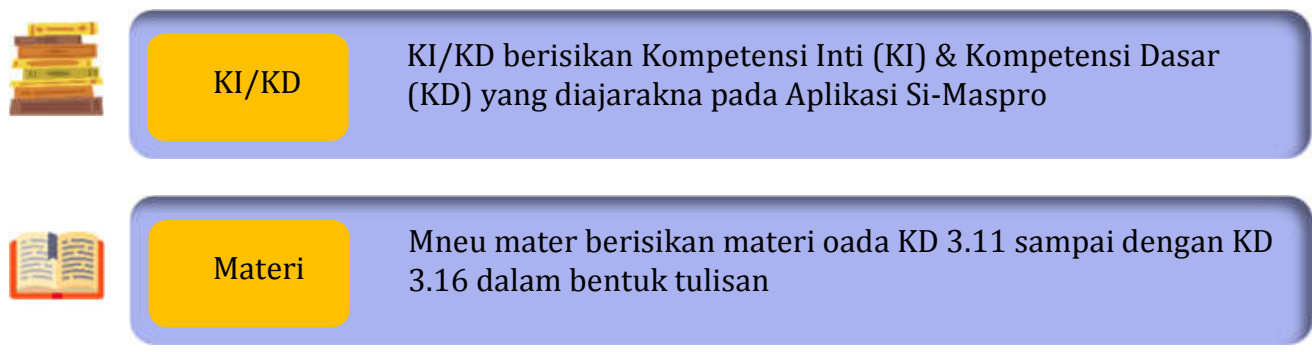




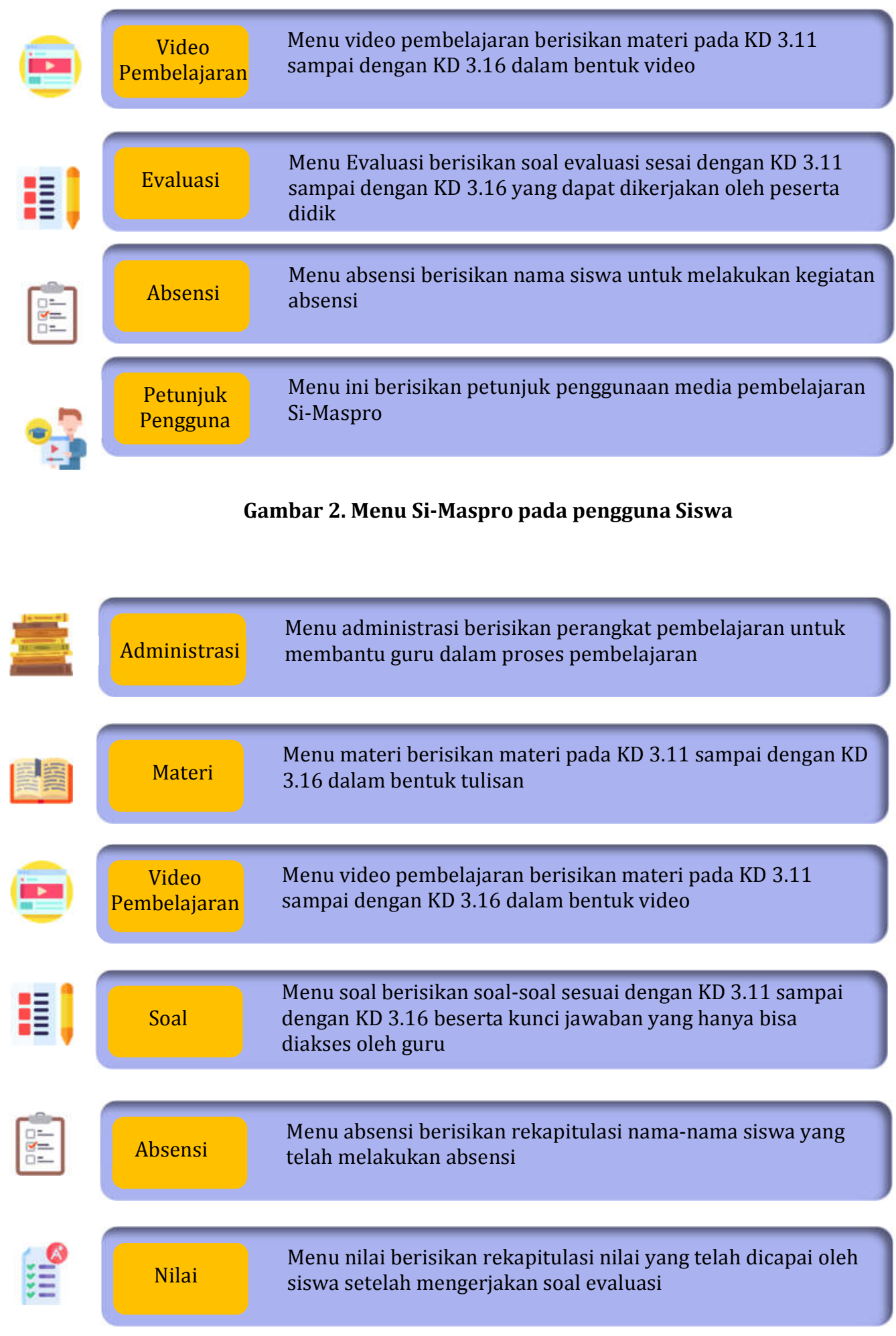




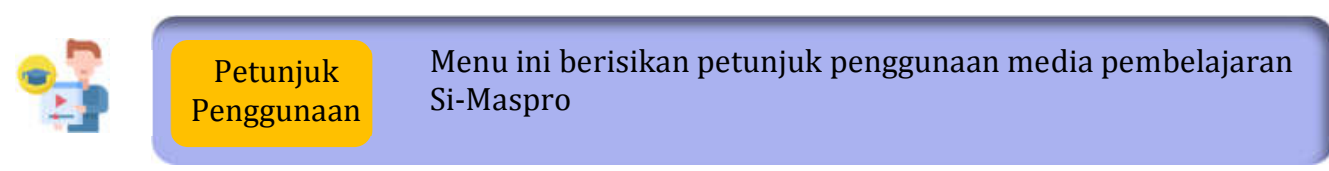

Gambar 3. Menu Si-Maspro pada Pegguna Guru

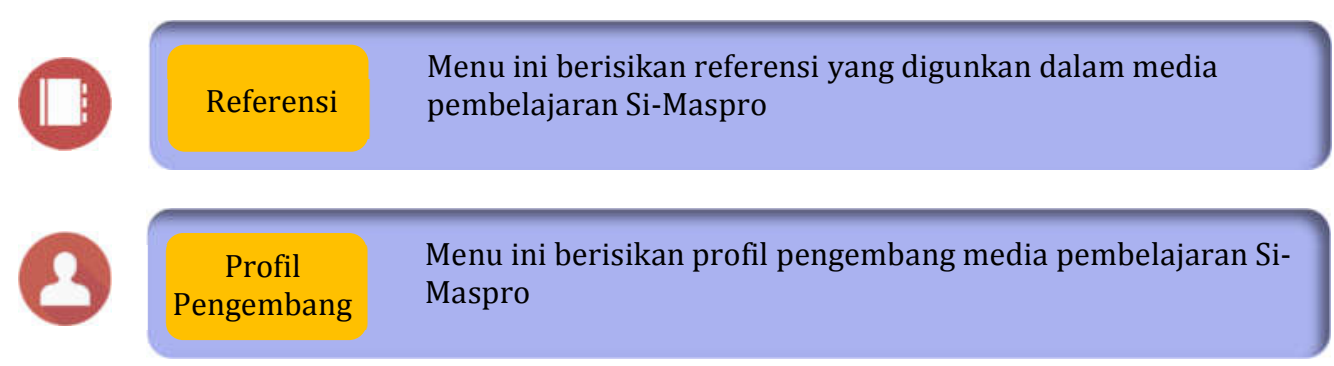

Gambar 4. Menu media pembelajaran Si-Maspro yang lainnya

Media pembelajaran Si-Maspro ini telah dilakukan validasi oleh materi, ahli media, serta uji coba kelompok kecil. Hasil validasi tersebut disajikan pada Tabel 1 sebagai berikut.

Tabel 1 data hasil validasi media pembelajaran Si-Maspro keseluruhan

\begin{tabular}{llll}
\hline No & Validasi & Presentase & Kriteria Validitas \\
\hline 1 & Ahli Materi & $93 \%$ & Sangat Valid \\
2 & Ahli Media & $99 \%$ & Sangat Valid \\
3 & Siswa Uji Coba Kelompok Kecil & $88 \%$ & Sangat Valid \\
Rata-Rata & $93 \%$ & Sangat Valid \\
\hline
\end{tabular}

Table used by permission (CSari, Kornelia Agata. 2020. Data hasil validasi media pembelajaran si-maspro keseluruhan.

Berdasarkan Tabel 1 diatas diperoleh rata-rata hasil validasi media pembelajaran SiMaspro sebesar 93\% sehingga dapat disimpulkan bahwa media pembelajaran Si-Maspro dinyatakan "Sangat Valid" dan layak digunakan untuk pembelajaran pada mata pelajaran Otomatisasi Tata Kelola Humas dan Keprotokolan kelas XII OTKP di SMK Negeri 1 Boyolangu Tulungagung.

Kelebihan yang dimiliki oleh media pembelajaran Si-Maspro yaitu telah memanfaatkan teknologi smartphone android yang telah dekat dengan kehidupan sehari-hari, peserta didik dapat memilih materi yang akan dipelajari berupa tulisan atau dalam bentuk video sehingga peserta didik dapat menentukan strategi belajarnya secara mandiri dan dapat meningkatkan hasil belajar, beberapa menu dapat diakses secara offline sehingga menghemat kuota internet, pengguna didesain untuk 2 pengguna sehingga memudahkan interaksi antara guru dan peserta didik dengan desain yang menarik dan kombinasi yang sesuai, lengkapnya cakupan materi pada mata pelajaran Otomatisasi Tata Kelola Humas dan Keprotokolan kelas XII pada semester ganjil, (Rifai et al., 2020), (Wijaya et al., 2019), (Tabuenca et al., 2015), (Mohd Suki and Mohd Suki, 2007), (Adawiah and Faiz, 2013).

Uji coba pemakaian dilakukan pada kelas eksperimen yaitu kelas XII OTKP 4 atau kelas yang menggunakan media pembelajaran Si-Maspro dan kelas kontrol yaitu kelas XII OTKP 3 atau kelas yang tidak menggunakan media pembelajaran Si-Maspro, dimana kelas kontrol 
menggunakan media pembelajaran berupa power point. Hasil uji coba pemakaian ini memperoleh hasil yang akan disajikan pada Tabel berikut.

Tabel 2 hasil uji coba pemakaian Si-Maspro

\begin{tabular}{clll}
\hline No & Kategori & Kelas Kontrol & Kelas Eksperimen \\
\hline 1 & Kemandirian Belajar & $85 \%$ & $88 \%$ \\
2 & Hasil Belajar Ranah Kognitif & $87 \%$ & $98 \%$ \\
\hline
\end{tabular}

Table used by permission (CSari, Kornelia Agata. 2020. Hasilujicobapemakaiansi-maspro.

Berdasarkan hasil pemaparan Tabel 2 diketahui adanya perbedaan kemandirian dan hasil belajar peserta didik antara kelas kontrol dan kelas eksperimen, dimana kelas eksperimen memperoleh rata-rata lebih tinggi dari kelas kontrol. Perbedaan kemandirian belajar peserta didik didukung dengan media pembelajaran Si-Maspro yang mudah diakses oleh peserta didik menggunakan smartphone, materi yang disajikan menarik, dan materi yang bervariatif dan dapat diakses kapan dan dimanapun sehingga mendukung peserta didik dalam mengatur, mengorganisasikan tujuan belajar, strategi belajar, dan kebutuhan belajarnya secara mandiri, (Tahar, 2006). Selain itu, hasil belajar peserta didik pada kelas eksperimen memperoleh rata-rata lebih tinggi dari kelas kontrol. Hal tersebut dikarenakan media pembelajaran Si-Maspro telah menyajikan materi dalam bentuk tulisan dan bentuk video untuk mempermudah peserta didik dalam memahami materi, desain yang menarik serta kombinasi warna yang sesuai pada media pembelajaran Si-Maspro ini dikembangkan untuk mempengaruhi tingkat perhatian dan gairah emosional tingkat kinerja memori dan memainkan peran positif dalam mempengaruhi retensi kognitif peserta didik, (Mohd Suki and Mohd Suki, 2007), (Adawiah and Faiz, 2013).

Tampilan media pembelajaran Si-Maspro dapat dilihat pada Gambar 5 sampai Gambar sebagai berikut.

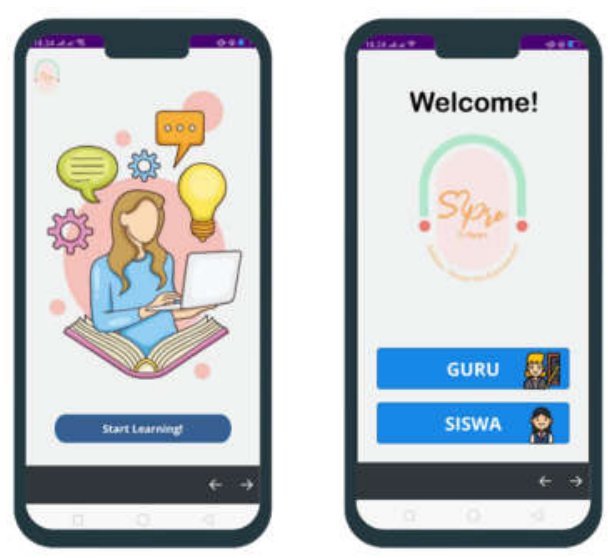

Gambar 5. Tampilan Awal Halaman Login 


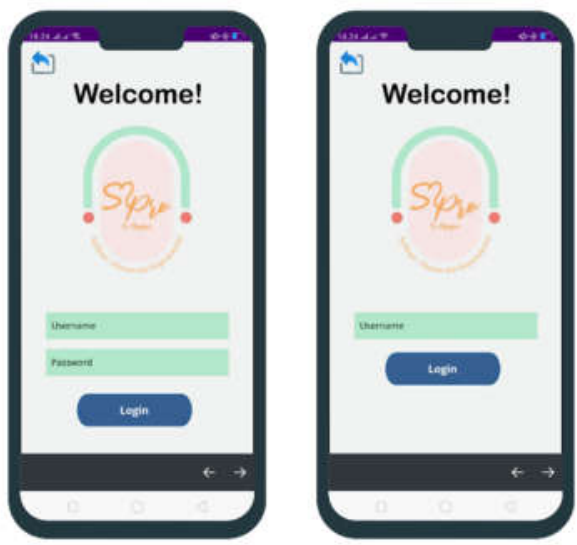

Gambar 6. Tampilan Halaman Login Si-Maspro
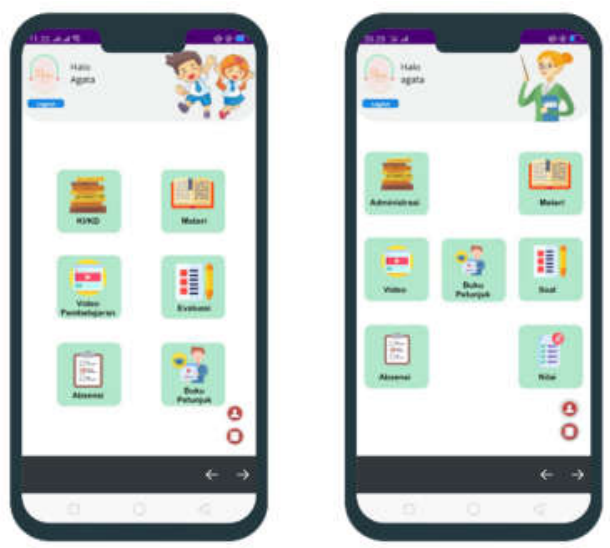

Gambar 7. Tampilan Dashboard Pengguna Siswa dan Guru
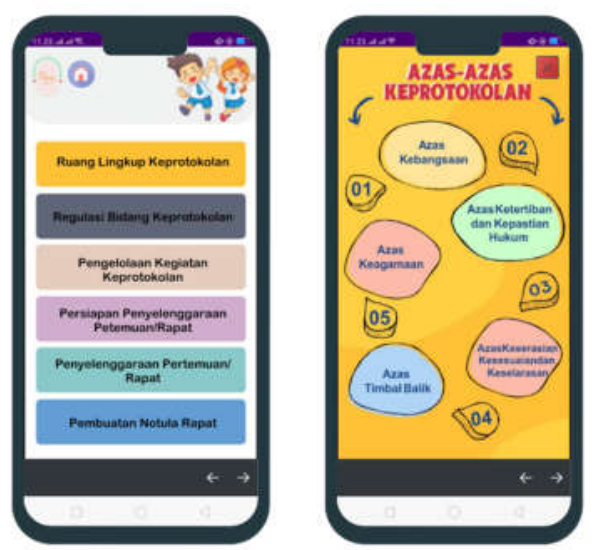

Gambar 8. Tampilan Materi 


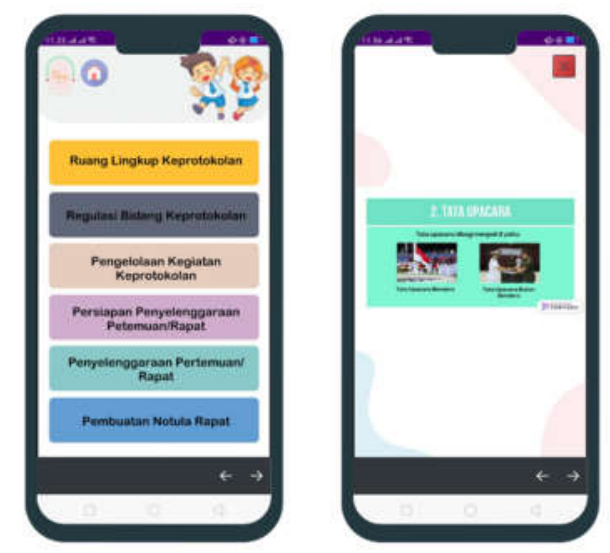

Gambar 9. Tampilan Video Pembelajaran

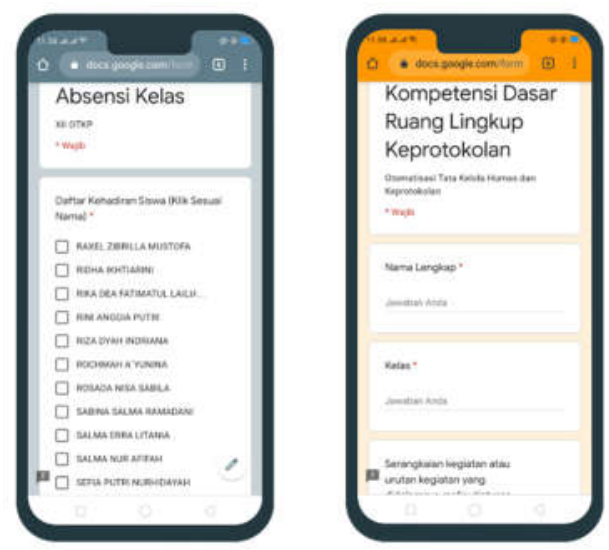

Gambar 10. Tampilan Absensi dan Evaluasi Peserta Didik

\section{Simpulan}

Penelitian dan pengembaangan ini mengahisilkan media pembelajaran berbasis android yang dibuat dengan bantuan software android studio. Media pembelajaran ini diberi nama SiMaspro atau Aplikasi Humas dan Keprotokolan. Si-Maspro mengemas materi pembelajaran Otomatisasi Tata Kelola Humas dan Keprotokolan pada semester ganjil atau KD 3.11 sampai dengan KD 3.16. Pengguna dapat diunduh secara gratis melalui link google drive https://bit.ly/2HfonJI, selain itu pengguna juga dapat mengakses buku petunjuk penggunaan media pembelajaran Si-Maspro melalui link https://bit.ly/3neinRp.

Media pembelajaran Si-Maspro ini telah dilakukan validasi oleh ahli materi, ahli media dan uji coba kelompok kecil dan dinyatakan "Sangat Valid" sehingga media pembelajaran SiMaspro dinyatakan layak digunakan dalam pembelajaran Otomatisasi Tata Kelola Humas dan Keprotokolan kelas XII OTKP. Si-Maspro juga terbukti dapat meningkatkan kemandirian dan hasil belajar peserta didik pada ranah kognitif dibuktikan dengan adanya perbedaan kemandirian belajar peserta didik kelas kontrol sebesar 85\% dan kelas eksperimen sebesar 88\%. Adapun hasil belajar pada kelas kontrol memperoleh rata-rata sebesar $87 \%$ dan kelas eksperimen sebesar 98\%, sehingga dapat disimpulkan bahwa adanya perbedaan kemandirian dan hasil belajar ranah kognitif antara peserta didik yang tidak menggunakan media pembelajaran Si-Maspro dan yang menggunakan media pembelajaran Si-Maspro. 
Media pembelajaran Si-Maspro mengemas materi pembelajaran Otomatisasi Tata Kelola Humas dan Keprotokolan pada KD 3.11 sampai dengan KD 3.16 di semester ganjil dan SiMaspro hanya dapat digunakan pada smartphone android saja. Oleh karena itu peneliti selanjutnya media pembelajaran ini dapat dikembangkan lagi pada materi semester genap dan dapat digunakan pada sistem operasi lain seperti $i O S$.

\section{Ucapan Terima Kasih}

Penulis mengucapkan terimakasih kepada Universitas Negeri Malang dan SMK Negeri 1 Boyolangu Tulungagung yang telah memberikan fasilitas dan izin penelitian, serta pihak-pihak yang telah membantu dalam proses penelitian dan pengembangan ini.

\section{Daftar Rujukan}

Adawiah, M., Faiz, M., (2013). The Influence of Colour on Memory Performance: A Review. Malaysian Journal of Medical Sciences, 3-9 7.

Firdausi, R., Santosa, A.B., (2016). Pengembangan Media Pembelajaran Mobile Learning Berbantuan Smartphone Android pada Mata Pelajaran Perekayasaan Sistem Aantan Studi pada Siswa Kelas XI TAV SMK Negeri 1 Nganjuk. Jurnal Pendidikan Teknik Elektro 05, 7.

Mohd Suki, Norbayah, Mohd Suki, Norazah, (2007). Mobile phone usage for m-learning: comparing heavy and light mobile phone users. Campus-Wide Info Systems 24, 355-365. https://doi.org/10.1108/10650740710835779

Rahmawati, E.M., Mukminan, M., (2018). Pengembangang m-learning untuk mendukung kemandirian dan hasil belajar mata pelajaran Geografi. jitp 4, 157. https://doi.org/10.21831/jitp.v4i2.12726

Restami, M.P., Antarajaya, I.N.S., Sugiani, K.A., (2019). Pengembangan Media Pembelajaran Berbasis Mobile Learning untuk Meningkatkan Kemampuan Literasi Visual dan Hasil Belajar. Jurnal Ilmiah Pendidikan Citra Bakti. https://doi.org/10.5281/ZENOD0.3551665

Rifai, A., Sulton, S., Sulthoni, S., (2020). Pengembangan Media Mobile Learning Sebagai Pendukung Sumber Belajar Biologi Siswa SMA. JKTP 3, 10-17. https://doi.org/10.17977/um038v3i12019p010

Suartama, I.K., Setyosari, P., Sulthoni, S., Ulfa, S., (2019). Development of an Instructional Design Model for Mobile Blended Learning in Higher Education. International Journal of Emerging Technologies in Learning (iJET) 14, 4. https://doi.org/10.3991/ijet.v14i16.10633

Susanto, F., (2018). Pengembangan Media Pembelajaran Manuscript Berbasis Android pada Mata Pelajaran Korespondensi Kelas X MP 1 di SMKN 2 Buduran. Jurnal Pendidikan Administrasi Perkantoran 6, 7.

Tabuenca, B., Kalz, M., Drachsler, H., Specht, M., (2015). Time will tell: The role of mobile learning analytics in $\begin{array}{llllll}\text { self-regulated learning. } & \text { Computers } \quad \& \quad \text { Education } & \text { 89, }\end{array}$ https://doi.org/10.1016/j.compedu.2015.08.004

Tahar, I., (2006). Hubungan Kemandirian Belajar dan Hasil Belajar pada Pendidikan Jarak Jauh. Jurnal Pendidikan Terbuka dan JarakJauh 7,11.

Warsita, B., (2018). Mobile Learning sebagai Model Pembelajaran yang Efektif dan Inovatif. Teknologi Pendidikan 14, 062. https://doi.org/10.32550/teknodik.v14i1.452

Wijaya, I.K., Bakri, R.A., Wutun, A.A., Fitriani, F., Mattoliang, A.A., (2019). The Effectiveness of Mobile Learning Based Android in Learning English Vocabularies. Int. J. Interact. Mob. Technol. 13, 226. https://doi.org/10.3991/ijim.v13i12.11167 